\title{
Implementasi Kesetaraan Gender pada Pendidikan Anak Usia Dini Di Sekolah
}

\author{
Selia Dwi Kurnia \\ Dosen IAIN BONE
}

\begin{abstract}
This article shows the implementation of gender equality in early childhood education in schools. Gender equality in the equality of position between men and women, without any differences with gender. Understanding gender equality in schools can make students not dominate what is their responsibility. Therefore, it is necessary to understand gender equality in schools so that students can explore their skills and abilities to be more qualified.
\end{abstract}

Keywords: Gender Equality, Early Childhood Education

\section{Pendahuluan}

Pada rentang usia 3-4 sampai 5-6 tahun, anak mulai memasuki masa prasekolah yang merupakan masa kesiapan untuk memasuki pendidikan formal yang sebenarnya di sekolah dasar. Menurut Montesssori masa ini ditandai dengan masa peka terhadap segala stimulasi yang diterimanya melalui pancaindera. Masa peka memiliki arti penting bagi perkembangan setiap anak. Itu artinya bahwa apabila setiap orangtua mengetahui anaknya telah memasuki masa peka dan mereka segera memberikan stimulasi yang tepat, maka akan mempercepat penguasaan terhadap tugas-tugas perkembangan pada usianya.

Dengan pesatnya perkembangan pada seluruh aspek yang disebabkan oleh perkembangan otaknya yang dapat mencapai $90 \%$ dari otak orang dewasa. Oleh karena itu, tugas utama dari seorang guru di sekolah untuk menyediakan berbagai macam permainan yang dapat memberikan stimulus yang sesuai dengan anak, sehingga anak dapat leluasa mengeksplor pengetahuannya.

Di sekolah juga anak-anak mempelajari peran gender yang berlaku di lingkungan sekolah. Masing-masing anak perempuan dan anak laki-laki mengembangkan perilaku, sikap, dan komitmen yang didefenisikan, langsung atau tidak langsung, sebagai atribut perempuan atau laki-laki yang bisa diterima. Terlebih, tiap anak memainkan peran gender mereka sesuai dengan pengalaman sehari-hari. Perasaan anak mengenai maskulinitas dan feminitas akan dipengaruhi oleh teman bermain mereka serta kesempatan bermain, mainan, jenis tontonaan televisi, dan terutama orang dewasa panutan (keluarga, tetangga, dan guru). Disinilah anak memperoleh pembelajaraan mengenai kesetaraam gender yang menjadi tanggungjawab guru di sekolah. 


\section{An-Nisa', Volume XI Nomor 2 Desember 2018}

\section{Kesetaraaan Gender}

Identitas gender merupakan kesadaran akan kelaki-lakian atau keperempuanan seseorang dan semua implikasinya dalam masyaraakat tertentu, merupakan aspek yang penting dalam perkembangan konsep diri. ${ }^{81}$

Jenis kelamin seorang siswa merupakan ciri yang terlibat dan abadi. Riset lintas-budaya menunjukkan bahwa peran gender merupakan hal pertama yang dipelajari individu dan bahwa semua masyarakat memperlakukan laki-laki berbeda dari wanita. Karena itu, perilaku peran gender atau peran jenis kelamin adalah perilaku yang dipelajari. Namun, rentang peran yang dimiliki oleh laki-laki dan wanita di seluruh budaya adalah luas. Apa yang dianggap sebagai perilaku alami bagi masing-masing gender lebih banyak didasarkan pada keyakinan budaya daripada keniscayaan biologis. Namun demikian, sejauh mana perbedaan biologis yang melekat, banyak perbedaan yang diamati antara laki-laki dan wanitaa dapat dikaitkan secara jelas dengan perbedaan pengalaman sosialisasi dini. ${ }^{82}$

Guru, biasanya tanpa menyadarinya, memperlihatkan ketidakadilaan gender (gender bias) dalam pengajaran di ruang kelas pada tiga hal utama: memperkuat stereotip gender, mempertahankan pemisahan jenis kelamin, dan memperlakukan laki-laki dan wanita dengan berbeda sebagai siswa. ${ }^{83}$

Menghindari stereotip. Guru seharusnya menghindari untuk menumbuhkan stereotip seksual. Misalnya, mereka dapat memberikan tugas di ruang kelas tanpa memandang gender, dengan menghindari secaraa otomatis menunjuk laki-laki maupun wanita membantu kegiatan fisik. Guru seharusnya juga menahan diri untuk mengucapkan stereotip, seperti “Anak laki-laki jangan menangis" dan "Anak perempuan jangan berkelahi” dan seharusnya menghindari untuk mencap siswa dengan istilah seperti tomboi. Guru seharusnya mendorong siswa yang memperlihatkan minat ke dalam kegiatan dan karier yang tidak terkait dengan stereotip budaya, seperti wanita yang menyukai matematika dan ilmu pengetahuan alam.

Menumbuhkan integrasi. Salah satu factor yang mengakibatkan stereotip gendr adalah kecenderungan anak laki-laki dan anak perempuan (khususnya di sekolah dasar) mempunyai sedikit teman dari jenis kelamin yang berbeda dan terlibat kebanyakan ke dalam kegiatan bersama anggota dari jenis kelamin mereka sendiri. Kadang-kadang guru mendorong hal ini dengan meminta anak laki-laki dan anak perempuan berbaris terpisah, menempatkan mereka di

\footnotetext{
${ }^{81}$ Diane E. Paplia,dkk, Human Development (Psikologi Perkembangan), (Jakarta:Kencana, 2008), h. 373.

${ }^{82}$ Robert E. Slavin, Psikologi Pendidikan:Teori dan Praktik, (Jakarta: Indeks, 2011), h. 154-155.

${ }^{83}$ Robert E. Slavin, Psikologi Pendidikan:Teori dan Praktik, (Jakarta: Indeks, 2011), h. 158-159.
} 
bangku yang terpisah menurut jenis kelamin, dan melakukan kegiataan olahraga yang terpisah untuk laki-laki dan wanita. Sebagai akibatnya, interaksi antara siswa dengan jenis kelamin yang sama. Namun, di kelas yang mendorong kerja sama lintas-jenis kelamin, anak-anak mempunyai pandangan yang kurang bersifat stereotip tentang kemampuan laki-laki dan wanita.

Memperlakukan wanita dan laki-laki dengan setara. Terlalu sering guru tidak memperlakukan laki-laki dan wanita dengan setara. Studi pengamatan tentang interaksi di ruang kelas telah menemukan bahwa guru lebih banyak berinteraksi dengan anak laki-laki daripada anak perempuan dan mengajukan lebih banyak pertanyaan kepada anak laki-laki, khususnya pertanyaan yang lebih abstrak. Guru pasti harus berhati-hati memberikan kesempatan yang setara kepada semua siswa untuk berpartisipasi di kelas, mengambil peran kepemimpinan, dan terlibat ke dalam semua jenis kegiatan.

Sekolah yang baik seharusnyaa juga bertanggungjawab terhadap parenting education/pendidikan menjadi orangtua yang baik. Bukan hanya bertugas mendidik muridmuridnya saja. Untuk pendidikan murid terhadap persamaan gender ada beberapa hal yang perlu diperhatikan sekolah: ${ }^{84}$

1. Jangan pernah ada pemisahan kelas di mana anak laki-laki dan anak perempuan belajar di tempat yang terpisah. Mereka akan semakin penasaran untuk mengetahui teman lawan jenisnya itu tanpa sepengetahuan kita. Berikan kesempatan kepada mereka untuk bersama-sam bergbung dalam proses belajar mengajar.

2. Berikan kesempatan yang sam dalam hal mengemukakan pendapat dan bertanya kepada anak laki-laki dan anak perempuan.

3. Memberikan tindakan disipliner yang sama baik terhadap anak laki-laki dan anak perempuan. Memberi hukuman tetap berlandaskan cinta, dan tidak dibenarkan memberikan hukuman dengan kadar lebih berat kepada anak laki-laki walaupun secara fisik mereka lebih kuat daripada anak perempuan.

4. Member pendidikan seks yang benar kepada anak laki-laki dan perempuan secara bersama-sama, sehingga mereka sama-samaa mengerti akan fungsi-fungsi organorgan genitalnya dan organ lawan jenisnya. Masih banyak ditemukan sekolah yang memisahkan anak laki-laki untuk mempelajari organ-organ reproduksinya saja, sementara anak perempuan yang berada di kelas terpisah hanya mempelajari organ-

\footnotetext{
${ }^{84}$ Suzie The Trainer, PAUD (Panduan Praktis Pendidikan Anak Usia Dini), (Jakarta:Elex Media Komputindo, 2012),h. 127-129.
} 


\section{An-Nisa', Volume XI Nomor 2 Desember 2018}

organ kewanitaannya saja. Teknik ini tidak dibenarkan, karena mereka perlu mempelajari organ-organ reproduksi dari lawan jenisnya juga.

5. Memberikan pendidikan seks sebaiknya disampaikan dengan raut wajah serius, tegas dan dengan bahasa ilmiah yang mudah dimengerti anak-anak. Bukan dengan wajah yang penuh dengan gurauan dan senyum-senyum atau tersipu malu. Pendidikan seks juga tidak dibenarkan bila membuat murid-murid harus mempraktikannya secara nyata.

6. Pihak manajemen sekolah juga tidak dibenarkan memungut uang sekolah yang lebih tinggi kepada murid laki-laki daripada murid perempuan.

7. Pengaturan jumlah murid laki-laki dan perempuan dalam 1 kelas sebaiknya sebanding dan tidak terlalu berbeda banyak. Misalnya jumlah murid laki-laki dalam 1 kelas itu adalah 20 orang, sedangkan anak perempuan berjumlah 18 orang atau 22 orang.

8. Guru laki-laki sebaiknya tetap membatasi pergaulannya agar tidak terlalu dekat dengan murid perempuan dan begitu juga sebaliknya.

9. Pihak manajemen sekolah sebaiknya mengambil tindakan tegas bila menemukan ada guru yang melakukan tindakan pelecehan seksuaal terhadap murid-muridnya baik kepada sesama jenis maupun lawan jenis karena itu merupakan tindak kekerasan terhadap anak.

10. Antar sesama guru yang saling tertarik, sebaiknya tetap menjaga profesionalisme untuk tidak bermesraan di depan murid-murid atau di lingkungan sekolah.

\section{Pengaruh Media Terhadap Perkembangan Gender}

Peran gender laki-laki dan perempuan dalam buku cerita anak maupun televisi digambarkan dengan pola gender-stereotip yang hampir sama. Dalam buku cerita, sering kali perempuan digambarkan sebagai sosok yang lebih pasif, dependen, dan memiliki ruang lingkup pekerjaan yang lebih terbatas dibandingkan dengan laki-laki. Sementara itu laki-laki digambarkan sebagai pribadi yang lebih asertif dan action oriented dibandingkan perempuan.

Di televisi, laki-laki sering kali digambarkan sebagai sosok yang agresif, tegas, professional, rasional, stabil, powerfull dan toleran, sementara perempuan memiliki karakter hangat, lebih berjiwa sosial, lebih emosional dan lebih bahagia, namun juga digambarkan sebagai individu yang tidak bekerja dan lebih banyak melakukan tugas rumah tangga dan mengasuh anak. 
Penelitian menunjukkan bahwa stereotip peran gender yang disajikan di media ini sangat memengaruhi perkembangan gender dan perilaku anak.

\section{Pengaruh Sekolah dan Guru Terhadap Perkembangan Gender}

Guru atau sistem di sekolah kadangkala kurang menerima perilaku independen, asertif, kompetitif, dan agresif yang sudah dibiasakan pada anak laki-laki sejak kecil. Sebaliknya, anak perempuan yang lebih aktiff secara verbal, yang pada umumnya menunjukkan perilaku yang lebih baik dan lebih mampu dalam mengikuti peraturan sekolah dibandingkan dengan anak lakilaki, mendapatkan yang lebih baik dari guru-gurunya.

Bagi anak laki-laki, sekolah mungkin bukanlah tempat yang menyenangkan karena mereka merasa guru lebih menyukai anak perempuan atau kesulitan untuk beradaptatsi dengan rutinitas di sekolah, sehingga wajar jika kemudian mereka banyak mengalami masalah dengan guru dan prestasi akademik mereka tidak sebaik anak perempuan.

Pencapaian prestasi akademik anak perempuan yang umumnya lebih tinggi dari anak laki-laki ini biasanya terjadi diawal-awal masa sekolah. Ketika sudah menginjak perguruan tinggi, capaian akademik anak perempuan seringkali dibawah potensi atau kemapuan yang dimilikinya. Setelah melakukan penelitian selal bertahun-tahun peneliti menemukan bahwa prestasi public, terutama dalam aktifitas yang kompetitif, seringkali ditakuti oleh remaja perempuan atau perempuan pada umumnya. Nenerapa dari mereka coping terhadap konflik yang dihadapinya ini dengan menyembunyikan kemampuan yang dimilikinya terutama dari anak lakilaki. Bahkan pada perempuan karir yang mencapai kesuksesannya akan berusaha untuk menyamarkan kesuksesannya ini dengan menonjolkan sifat femininnya di bidang yang lain, misalnya mereka tidak ingin hanya menjadi wanita karir yang super, namun juga istri dan ibu yang super.

\section{Pendidikan Anak Usia Dini}

Pendidikan anak usia dini merupakan program pendidikan yang dilakukan bagi anak sejak berusia 0 hingga memasuki usia sekolah dasar. Di Indonesia, rentang usia PAUD 0-6 tahun. Pendidikan anak usia dini (PAUD) adalah suatu upaya pembinaan yang ditujukan kepada anak sejak lahir hingga usia 6 tahun yang dilakukan melalui pemberian rangsangan pendidikan untuk membantu pertumbuhan dan perkembangan jasmani dan rohani agar anak memiliki kesiapan dalam memasuki pendidikan lebih lanjut. 


\section{An-Nisa', Volume XI Nomor 2 Desember 2018}

PAUD memiliki arti penting, karena di dalamnya terkandung unsur pendidikan, pengasuhan, dan pengembangan potensi anak yang secara langsung terkait dengan orang tua, keluarga, dan masyarakat.

\section{Landasan Penyelenggaraan PAUD}

Penyelenggaraan pendidikan anak usia dini haruslah didasarkan pada berbagai landasan, landasan yurudis, landasan filosifis, dan religious serta landasan keilmuan baik teoritis maupun empiris, dengan penjelasan sebagai berikut: ${ }^{85}$

\section{Landasan Yuridis}

Pendidikan anak usia dini merupakan bagian dari pencapain tujuan pendidikan nasional, sebagaimana diatur dalam undang-undang No.2 tahun 1989 tentang Sistem Pendidikan Nasional, yaitu mencerdaskan kehidupan bangsa dan mengembangkan manusia Indonesia seutuhnya, yaitu manusia yang beriman dan bertaqwa terhadap Tuhan Yang maha esa dan berbudi luhur, memiliki pengetahuan dan keterampilan, kesehatan jasmani dan rohani, kepribadian yang mantap dan mandiri serta tanggung jawab kemasyarakatan dan kebangsaan.

Selanjutnya, pada Pasal 28B ayat 2 dinyatakaan bahwa setiap anak berhak atas kelangsungan hidup, tumbuh dan berkembang serta berhak atas perlindungan dari kekerasan dan diskriminasi, sedangkan pada Pasal 28C ayat 2 dinyatakan bahwa setiap anak berhak mengembangkan diri melalui pemenuhan kebutuhan dasarnya, berhak mendapatkan pendidikan dan memperoleh manfaat dari ilmu pengetahuan dan teknologi, seni, dan budaya, demi meningkatkaan kualitas hidupnya dan demi kesejahteraaan umat manusia.

Adapun pada Pasal 28 tentang Pendidikan Anak Usia Dini dinyatakan, bahwa: (1) Pendidikan Anak Usia Dini diselenggarakan sebelum jenjang pendidikan dasar, (2) Pendidikan Anak Usia Dini dapat diselenggarakan melalui jalur pendidikan formal, nonformal, dan/atau informal, (3) Pendidikan Anak Usia Dini jalur pendidikan formal: TK, $\mathrm{Ra}$, atau bentuk lain yang sederajat, (4) Pendidikan Anak usia Dini jalur pendidikan nonformal: KB, TPA, atau bentuk lain yang sederajat, (5) Pendidikan Anak Usia Dini jalur pendidikan informal: pendidikan keluarga atau pendidikan yang diselenggarakan oleh lingkungan, (6) Ketentuan mengenai Pendidikan Anak Usia Dini sebagaimana dimaksud dalam ayat (1), ayat (2), ayat (3), dan ayat (4) diatur lebih lanjut dengan peraturan pemerintah.

85 Herdina Indrijati, Psikologi Perkembangan Dan Pendidikan Anak usia Dini: Sebuah Bunga Rampai, (Jakarta:Kencana, 2016),h. 156-158. 


\section{Landasan Filosofis dan Religi}

Selanjutnya, berdasarkan aspek pedagogis, masa usia dini merupakan masa peletak dasar atau pondasi awal bagi pertumbuhan dan perkembangan selanjutnya. Artinya, masa kanak-kanak yang bahagia merupakan dasar bagi keberhasilaan di masa dating dan sebaliknyaa. Untuk itu, agar pertumbuhan dan perkembangan tercapai secara optimal. Maka dibutuhkan situasi dan kondisi yang kondusif pada saat memberikan stimulasi dan upaaya pendidikan yang sesuai dengan kebutuhan anak yang berbeda satu dengan lainnyaa (individual differences). Berdasarkan landasan filosofis dan religi, secara ontologism anak sebagai makhluk individu yang memiliki aspek biologi, psikologi, sosiologis, dan antropologis.

\section{Landasan Keilmuan}

Konsep keilmuan Pendidikan Anak usia Dini bersifat isomorfis, artinya kerangka keilmuan PAUD dibangun dari interdisiplin ilmu antara lain psikologi, fisiologi, ilmu pendidikan anak (pedagogi), sosiologi, antropologi, humaniora, manajemen, kesehatan dan gizi serta neurosains (ilmu tentang perkembangan otak manusia).

\section{Pendekatan Dalam Pendidikan Anak Usia Dini}

Untuk memenuhi aspek-aspek dalam perkembangan anak, baik aspek fisik, kognitif, sosial emosional, maupun bahasa serta aspek lainnya seperti agama dan moral, kemandirian dan seni, maka perlu dilakukan berbagai pendekatan yang meliputi: ${ }^{86}$

1. Berorientasi pada Kebutuhaan Anak

Kegiatan pembelajaran pada anak harus senantiasa berorientasi kepada kebutuhan anak. Anak usia dini ialah anaak yang sedang membutuhkan upaya pendidikan untuk mencapai optimalisasi semua aspek perkembangan baik perkembangan fisik maupun psikis, yaitu intelektual, bahasa, motorik, dan sosio-emosional. Dengan demikian berbagai jenis kegiatan pembelajaraan hendaknya dilakukan melalui analisis kebutuhan yang disesuaikaan dengan berbagai aspek perkembangan dan kemampuan pada masing-masing anak. Kegiatan pembelajaran pada anak usia dini haarus senantiasaa berorientasi kepada kebutuhan anak untuk mendapatkan layanan pendidikan, kesehatan dan gizi yang dilaksanakan secara integratif dan holistik.

\footnotetext{
${ }^{86}$ Herdina Indrijati, Psikologi Perkembangan Dan Pendidikan Anak usia Dini: Sebuah Bunga Rampai, (Jakarta:Kencana, 2016),h. 159-160.
} 


\section{An-Nisa', Volume XI Nomor 2 Desember 2018}

2. Belajar Melalui Bermain atau Bermain Sambil Bermain

Bermain merupakan pendekatan dalam melaksanakan kegiatan pendidikan anak usia dini, dengan menggunakan strategi, metode, materi/bahan dan media yang menarik agar mudah diikuti oleh anak. Melalui bermain anak diajak untuk bereksplorasi, menemukan, memanfaatkan, dan mengambil kesimpulan mengenai benda di sekitarnya.

3. Pendekatan Kreatif dan Inovatif

Proses kreatif dan inovatif dapat dilakukan melalui kegiatan-kegiatan yang menarik dan membangkitkan rasa ingin tahu anak untuk berpikir kritis dan menemukan hal-hal baru.

\section{Lingkungan yang Kondusif}

Lingkungan harus diciptakan sedemikian rupa, sehinggaa menarik dan menyenangkan dengan memperlihatkan keamanan serta kenyamanan yang dapat mendukung kegiatan belajar melalui bermain.

5. Menggunakan Pembelajaran Terpadu

Model pembelajaran terpadu berdasarkan tema yang menarik dan dapat membangkitkan minat anak-anak (center of interest). Hal ini dimaksudkan agar anak mampu mengenal berbagai konsep ssecara mudah dan jelas, sehingga pembelajarn menjadi mudah dan bermakna bagi aanak.

6. Mengembangkan Berbagai Kecakapan Hidup

Mengembangkan keterampilan hidup dapat dilakukan melalui berbagai proses pembiasaan. Hal ini dimaksudkan agar anak mampu menolong diri sendiri, mandiri, dan bertanggungjawab serta memiliki disiplin diri, mampu bersosialisasi dan memperoleh bekal keterampilan dasar yang berguna untuk kelangsungan hidupnya.

7. Menggunakan Berbagai Media dan Sumber Belajar

Media dan sumber pembelajaran dapat berasal dari lingkungan alam sekitar atau bahanbahan yang sengaja disiapkan.

\section{Prinsip-Prinsip Pendidikaan Anak Usia Dini}

Terdapat berbagai pendekatan dan prinsip pendidikan anak usia dini, yaitu: ${ }^{87}$

1. Konsep Belajar Sambil Bermain

Bermain adalah suatu kegiatan yang dilakukan berulang-ulang dan menimbulkan kesenangan/kepuasan bagi diri seseorang (Piaget). Diharapkan melalui bermain dapat memberi

\footnotetext{
87 Herdina Indrijati, Psikologi Perkembangan Dan Pendidikan Anak usia Dini: Sebuah Bunga Rampai, (Jakarta:Kencana, 2016),h. 160-165.
} 
kesepakatan anak bereksplorasi, menemukan, mengekspresikan perasaan, berkreasi dan belajar secara menyenangkan. Selain itu, melalui bermain dapat membantu anak mengenal tentang diri sendiri, dengan siapa iya hidup serta melalui bermain anak akan memperoleh pengetahuan.

\section{Kedekatan dengan Lingkungan}

Pendidikan merupakan usaha sadar yang dilaksanakan sengaja dan terencana untuk membantu anak mengembangkan potensi secara optimal, sehingga anak mampu beradaptasi dengan lingkungannya. Pengertian ini mengandung makna bahwa esensi yang hakiki dari tujuan akhir pendidikan yaitu kemampuan anak melakukan adaptasi dengan lingkungan dalam arti yang luas. Dengan demikian, tujuan pendidikan seharusnya menjadi dasar untuk mengarahkan berbagai proses pendidikan (pembelajaran) agar mendekatkan anak dengan lingkungan. Dengan demikian, pendidikan yang diberikan akan dapat dimaknai dan berguna bagi anak ketika beradaptasi dengan lingkungannya.

3. Alam sebagai Sarana Pembelajaran

Prinsip ini didasarkan pada beberapa teori pembelajaran yang menjadikan alam sebagai sarana yang tak terbatas bagi anak untuk mengeksplorasi dan berinteraksi dengan alam dalam membangun pengetahuannya. Out Bond Learning merupakan salah satu model pembelajaran dimana hampir 90\% kegiatan dilakukan dengan berinteraksi dengan alam tanpa ada kekangan. Dalam pembelajaran ini anak diajarkan untuk dapat membangun ikatan emosional diantara individu (anak), yaitu dengan menciptakan kesenangan belajar, menjalin hubungan, dan memengaruhi memori dan ingatan yang cukup lama akan bahan-bahan yang telah dipelajari.

\section{Anak Belajar Melalui Sensorinya}

Anak memperoleh pengetahuan melalui memorinya. Oleh karena pembelajaran pada anak hendaknya mengarahkan anak pada berbagai kemampuan. Teori multiple intelegent mengisayaratkan bahwa pada dasarnya kecerdasan merupakan potensi biopsikologi, artinya semua anggota jenis makhluk yang bersangkutan mempunyai potensi untuk menggunakan sekumpulan bakat kecerdasan yang dimiliki oleh jenis makhluk itu. Jadi, bakat kecerdasan yang dimiliki tidak hanya satu atau tunggal tetapi ada beberapa kecerdasan (kecerdasan majemuk). Jenis kecerdasan majemuk ini terdiri dari kecerdasan ruang, kecerdasan gerakan badan, kecerdasan musik, kecerdasan antar pribadi, kecerdasan intra-pribadi, kecerdasan verbal, kecerdasan numerik, bahkan sampai pada kecerdasan menyenangi lingkungan alam.

\section{Mengembangkan Keterampilan Hidup}

Pembelajaran pada anak hendaknya membekali anak untuk memiliki keterampilan hidup dalam arti yang sangat sederhana sesuai kemampuan anak. 


\section{An-Nisa', Volume XI Nomor 2 Desember 2018}

Keberhasilan proses pendidikan dapat terlihat dari perubahan perilaku yang positif pada anak, Lembaga pendidikan anak usia dini hendaknnya membekali anak dengan berbagai keterampilan hal ini sebagai acuan dasar dalam membimbing anak untuk memiliki ketermapilan yang mempu dijadikan sandaran dalam keberlangsungan hidup anak.

6. Anak sebagai Pembelajar Aktif

Pendidikan hendaknya mengarahkan anak untuk menjadi pebelajar yang aktif. Pendidikan yang dirancang secara kreatif akan menghasilkan pebelajar yang aktif. Anak-anak akan terbiasa belajar dan mempelajari berbagai aspek pengetahuan, keterampilan dan kemampuan melalui berbagai aktifitas mengamati, mencari, menemukan, mendiskusikan, menyimpulkan dan mengemukakan sendiri berbagai hal yang ditemukan pada lingkungan sekitar.

\section{Daftar Pustaka}

Diane E. Paplia,dkk. Human Development (Psikologi Perkembangan). Jakarta: Kencana. 2008.

Herdina Indrijati. Psikologi Perkembangan Dan Pendidikan Anak usia Dini: Sebuah Bunga Rampai. Jakarta: Kencana. 2016.

Robert E. Slavin. Psikologi Pendidikan:Teori dan Praktik. Jakarta: Indeks. 2011.

Suzie The Trainer. PAUD (Panduan Praktis Pendidikan Anak Usia Dini). Jakarta: Elex Media Komputindo. 2012. 